University for Business and Technology in Kosovo

UBT Knowledge Center

Nov 2nd, 3:00 PM - 3:15 PM

\title{
Legislative Framework Of The Republic Of Kosovo In The Area Of Border And Migration And Its Accordance With Eu Acquis
}

Shkelzen Sopjani

University of Prishtina

Follow this and additional works at: https://knowledgecenter.ubt-uni.net/conference

Part of the Law Commons

\section{Recommended Citation}

Sopjani, Shkelzen, "Legislative Framework Of The Republic Of Kosovo In The Area Of Border And Migration And Its Accordance With Eu Acquis" (2013). UBT International Conference. 49.

https://knowledgecenter.ubt-uni.net/conference/2013/all-events/49

This Event is brought to you for free and open access by the Publication and Journals at UBT Knowledge Center. It has been accepted for inclusion in UBT International Conference by an authorized administrator of UBT Knowledge Center. For more information, please contact knowledge.center@ubt-uni.net. 


\title{
Legislative Framework Of The Republic Of Kosovo In The Area Of Border And Migration And Its Accordance With Eu Acquis
}

\author{
Shkelzen Sopjani \\ Law Sciences, Prishtina University \\ Pristina, Kosovo
}

\begin{abstract}
The area of border and migration is fairly new in Kosovo, especially when considering legislation adopted and en-force related to this area. The initial Law (Law on Foreigners) dealing with migration was drafted only in 2008 (after Kosovo declared its independence) and entered into force in 2009, while the first legislative piece that 'dealt' with border and migration was adopted only in 2005, that was the UNMIK Regulation No. 2005/16, approved by the Special Representative of the Secretary General of UN. This regulation (on the Movement of Persons Into and Out of Kosovo) consisted of only 28 articles and covered the areas of entry, stay and exit of 'foreigners', refugees as well as border control. These areas are now regulated with three specific Laws and number of sub-legal acts (Administrative Instructions) Standard Operation Procedures (SOP's).This area of legislation deals directly with the national security related concerns, as well as directly relates with the Government of Kosovo's top priorities; one being visa liberalization of Kosovo with European Union; and the highest strategic priority of the Kosovo's Government, being the full integration of the Republic of Kosovo into the European Union, that requires the harmonization of Kosovo's Legislation with the EU Acquis Communitaire. This study aims to give an overall picture to the Kosovo's legislation in the area of Border and Migration Management and its compatibility with the EU Acquis covering the respective area.
\end{abstract}

Keywor ds: Border, Migration, Legislation, EU, Foreigners.

\section{Introduction}

With the declaration of independence by the Kosovo Parliament, on February 17, 2008, as well as in accordance with the Ahtisaari's Proposal, Kosovo institutions had to adopt a number of laws, regulating a number of areas, which until this period were not regulated or were under the competences of Un ited Nations Mission in Kosovo (UNMIK). These areas, among others included: Border and Migration Management: Security Sector, etc. Therefore, on May 21, 2008 Kosovo Parliament approved two laws, and that Law No 2008/03-L-066 on Asylum and Law 2008/03-L-065 on Integrated Management and Control of State Border. In this regard, on December 162008 the Kosovo Parliament approved the Law no.2008/03-L-126 on Foreigners Finally, the Law No.2009/03-L-136 on Granting the Permit for Work and Employment of Foreign Citizens on the Republic of Kosovo (RKS) were approved on July 172009 by the Kosovo Parliament. While the Law on Foreigners regulates the entry, stay and exit of Foreigners in Kosovo, the scope of the law on Asylum is to regulate the conditions and the procedures for the recognition, refusal and revocation of the Asylum, Temporary Protection and Complementary Protection, as well as the rights and obligations of the asylum seekers as well as persons enjoying refugee status in Kosovo. Finally, the Law on Border Control regulates the border control, competences of the police within the territory and the cooperation of border authorities with other institutions (both domestic and international).Initial laws that were adopted by Kosovo Parliament did set the basics, however there were many gaps and in some instances, conflicts between these same laws.

The above mentioned gapes and conflicts between these laws started to present difficulties for the authorities that were applying these laws, and in this regard, the Government of Kosovo (GoK) decided to review/amend these laws and where necessary to draft new ones, with the aim of avoiding theses gaps and conflicts as well as their harmonization with the European Union (EU) Acquis in this area. The GoK in June 2012 received from the EU the Roadmap for the Vis a Liberalization with Kosovo. This roadmap contains four pillars; Readmission and Reintegration, Document Security, Border and Migration Management and Public Security. This roadmap addresses three basic criteria being; 
Kosovo's record in adopting or amending in line with the EU Acquis the legislation set out in this roadmap; Kosovo's record in implementing this legislation; and the expected migratory and security impacts of the liberalization of the visa regime with Kosovo.

This roadmap, regarding the area of Border and Migration management, sets twenty (20) legis lative acts adopted by EU, with which Kosovo's legislation should be harmonized.

Even before the visa liberalization process, GoK did pledge that with the aim of Kosovo's integration in EU (being one of the top priorities of GoK), GoK will harmonize all of its legis lation with that of EU and with this aim GoK decided to assign specific officers specialized on EU Legis lation in every Legal Department of every Ministry, whose main duty would be to ensure that every legislative act sponsored by the GoK is in line with EU legislation in the respective area. Finally, with this aim, GoK did establish the Ministry for European Integration, whose legal department should be the final organ to make sure that every piece of legislation sponsored by the GoK is in line with the EU Acquis in the respective area. This pledge is also shown in the Regulation No. 09/2011on the work of the Government of the RKS.

Finally, while there were gaps and conflicts in the laws covering the area of Border and Migration management, laws approved during 2008 by the Kosovo Parliament and while these gaps and conflicts were supposed to be addressed during the amendment procedure of these laws in 2011, there were still some gaps, while there were some discrepancies between these laws and the EU legislation, which GoK addressed.

\section{Legislative Framework In The Area Of Border Management}

The area of border management was initially regulated with the Regulation No. 2001/10 on the Prohibition of Unauthorized Border/Boundary Crossings, that was implemented through Administrative Direction No. 2003/18 of 30 July 2003 Amending UNMIK Administrative Direction No. 2001/15. This regulation contained total of eight articles, three of which were technical (regulating applicable law, implementation and entry into force). This regulation in its article 1 stated that "Boundary" means the line of division between Kosovo and Serbia, and between Kosovo and Montenegro" while "Border" means the Kosovo section of the internationally recognized border between the Federal Republic of Yugoslavia and the former Yugoslav Republic of Macedonia (FYROM), and between the Federal Republic of Yugoslavia and the Republic of Albania.

This regulation regulated only the designation of border/boundary crossing points, it defined the illegal border/boundary crossing while it set fines for those who cross illegally and in its article four regulated the Treatment of Bona Fide Refugees and Internally Displaced Persons. As it can be seen, this regulation as well as its administrative directives was very poor, while it failed to regulate even the basic functions related to border, like: Border Check, Border Surveillance, Competent Authority, Cooperation between Agencies involved in BCP activities, etc.

This regulation represented the only legal basis related to Border Management up until July 1 2008, when Law No.2008/03-L-065 on Integrated Management and Control of State Border, entered into force. Compared to the above mentioned regulation, this law was way more comprehensive, but also this law failed to regulate some basic issues related to Border Management. This law failed to define the competent authority, while very partially regulates border control, by not providing any provision on first and secondary border line checks as well as basic and thorough border checks. Despite the title of this law, in any of its articles does this law regulate Integrated Border Management, nor the cooperation and coordination between the agencies involved in border control! Having all this in mind and when looking closely the provisions of this law, one can easily see that these provisions are poor, while some of them lack some basic components of a legal provision and seem to be more like 'political' statements rather than provisions of the law, with a clear aim and message. Despite this, this law does not contain any penalty provisions, providing sanctions for those violating the provisions of the law (like: avoiding border check, misuse of pers onal data, etc.).

Finally, even though the GoK pledge for harmonizing its legislation with that of EU, and the fact that at the time of drafting of this law, EU had already regulated the area of Border Control, this law was not even closely in line with the legislation of EU covering this area. While EU legislation covering the area of border control is extensive, including the 'Schengen Borders Code', and it dates before the actual 
drafting of this law, drafters of this law failed to incorporate necessary arrangement provided with the EU Acquis in the area of border into this law, therefore this law was not in harmony with EU Acquis, while it created a lot of difficulties for agencies implementing this law, mainly Kosovo Border Police.

\section{Border Control and Surveillance}

Due to gaps and confusion that the Law 2008/03-L-065 on Integrated Management and Control of State Border had and the fact that this law was not in harmony with the EU Acquis covering this res pective area, GoK in its legislative agenda for 2011, decided to draft a new law regarding Border management. In this regard, with the decision of the Minister of Internal Affairs, a Work Group with a mandate of drafting a new law for Border Control and Surveillance was established on March 2011. After about six (6) month, GoK finalized the draft Law on State Border Control and Surveillance and on October 04, 2011, sent it to Parliament for final scrutiny and approval. This law was approved by parliament on December 21, 2011 and promulgated by the Decree of the President of the RKS No.DL-001-2012, on January 06, 2012. This law contains 64 articles and it is in harmony with the EU Acquis covering the area of Border management and that with the Schengen Bord ers Code. Initially, the scope of the Law on State Border Control states as follows: "This law applies to all persons who cross the state border of the RKS, without hereby jeopardizing the rights of refugees and persons seeking international protection, particularly in relation to the principle of non refoulement". This is in line with the Article 3 of the Schengen Borders Code (Regulation 562/2006). In addition, this law (chapter II) regulates the competencies and authorizations of the body conducting border control, as well as the principles that are to be taken into consideration when conducting border control. This chapter is fully in line with the Article 6 and Chapter III of the Schengen Borders Code. Chapter III of the Law (regulating crossing of the state border) is fully in line with provisions of Article 4 of the Schengen Borders Code, while chapter IV of the Law (establishing rules for conducting border checks) is fully in line with Chapters II and IV of the Schengen Borders Code. Chapter V of the law contains provisions setting out rules for categorization of border crossing points, determining the border crossing zones, as well as establishing specific rules for movement and conducting activities within the Border Crossing Points (BCPs) and Border Crossing Zones (BCP zones).

Chapter VI of this Law, dealing with border surveillance transposes provisions contained in Article 12 of the Schengen Borders Code, while Chapter VII sets the rules applied in relation to marking, maintain, etc., the border line. Chapter VIII regulates the measures taken by border police within the territory of the country, while Chapter IX contains provisions obliging all bodies involved in border management to cooperate, specifically based on the National Integrated Border Management (IBM) Strategy, and establishes the National Centre for Border Management (NCBM). Chapter X regulates international cooperation and Chapter XI sets specific rules dealing with personal data and management of such data. Lastly, Chapter XII contains penalty provisions, while Chapter XIII sets provisional and final provisions (including abrogation or incorporation of rules provided for by other legal acts).

The most significant changes that this law introduced, include: The establishment of the NCBM, with the aim of achieving effective coordination, facilitation of exchange of information and data and greater efficiency of the system for integrated border management; in introduced detailed provisions on data protection regarding data collected while performing border control activities; it included the penalty provisions for potentialviolations of the provisions of this law; provided for detailed provisions dealing with border checks, including both minimal and detailed border checks; obligation for a irliners to provide passenger information in advance and; provided for special categories for whom, special rules apply when conducting border check. All these provisions were lacking in previous legislative acts of the RKS, while all these provisions are also present in the Schengen Borders Code (Regulation 562/2006). Based on the Report of the Commission to the European Parliament and The Council on progress by Kosovo in fulfilling the requirements of the visa liberalization roadmap, dated on February 08, 2013 this law incorporates the criteria provided with the Schengen Regulation, however, according to the expert doing the assessment on border related is sues there is a terminological confusion in some articles of this law. Granted, English translation of this law was poor, however according to the Constitution of Kosovo, article 5, official language in Kosovo are Albanian and Serbian, therefore 
versions in these two languages should have been consulted and not the English, considering that English version does not produce any legal effect. However, GoK,s revised Legis lative Agenda for 2013 the amendment of this Law has been introduced (mainly to be seen as the expert's recommendations have been taken into account) and the amendment of this law has taken place introducing some minor and mainly technical amendments, including the redefinitions on border check and border control, according to the EU Schengen Regulation, while it also renamed the previous law from Law on Border Control and Surveillance into Law on Border Control.

There are another eight (8) administrative instructions implementing this law, including the AI No. 30/2012 on Rules on Local Border Traffic and Local Border Traffic Permit fully transposes provisions of the Local Border Traffic Regulation (Regulation 1931/2006). This law invalidated the Law No.2008/03-L-065 on Integrated Management and Control of State Border, while it had empowered the National IBM Strategy, by making it part of this Law.

Finally, this Law did address the gaps and confusion that was created among the Agencies involved in the Border Management and facilitated better control of the borders while it created additional mechanism for more efficient and effective fight against illegal migration, smuggling of goods and other materials through border. This law is in harmony with EU Acquis covering this respective area while it incorporates almost all of the related provisions of the Schengen Borders Code.

\section{Cooperation between Authorities Involved on Integrated Border Management}

Report of the Commission to the European Parliament and The Council on progress by Kosovo in fulfilling the requirements of the vis a liberalization roadmap, dated on February 08, 2013 requires, among others also to draft a law on inter-agency cooperation that defines the roles and responsibilities of all public authorities involved in integrated border/boundary management, while it also states that Kosovo should, therefore, draft legislation that defines the roles and responsibilities of all public authorities involved in border/boundary management, including operational cooperation and information sharing for the purpose of preventing and combating irregular migration and cross -border crime.

This recommendation from the report seemed surprising considering that neither countries in EU nor none of the Balkan countries that already completed the visa liberalization process with EU Schengen have such a law. Cooperation between agencies in EU as well as Balkan Countries, including Kosovo has been addressed through National Strategies for IBM, while EC did produce a document on Guidelines for Integrated Border Management. This document defines the concept of IBM; provides practical examples of implementation of IBM and; provides guidance on the framework for the establishment of national IBM strategies and action plans by a coordination group of all agencies involved in border management. In addition, this document states that: Since the field of IBM covers a wide range of topics and tackles complex and sometimes controversial issues, a work plan has to be developed jointly by all relevant stakeholders. Such a plan consists of two documents: The national IBM strategy, where the strategic and operational aims ("objectives") are listed, which should lead to improved cooperation; the national IBM action plan, which identifies specific actions that have to be taken to reach the objectives of the strategy. Timing, costs and responsibilities are assigned as well. Kosovo has a National Strategy on IBM since May 2009 with a very detailed action plan attached to this strategy, while the new version has been drafted already and is pending approval by the GoK (by October 2013). Kosovo's IBM strategy and Action plan contains all the requirements provided for in the European Commission (EC) guidelines, while it provided for detailed roles, duties and responsibilities of all agencies involved in IBM. In addition, The Law on Border Control, in its article 48 incorporates this strategy as part of this law; bring it in a higher level, compared to other regional and EU countries. This article states that: State bodies involved in border management assist one another, and cooperate closely and continuously, aiming to achieve more efficient and effective border control; the cooperation from paragraph 1 of this Article is achieved through the strategy for Integrated Border Management. Having all this in mind, Kosovo was considered to be a head of other countries regarding the IBM, while also the Commission Staff Working Document accompanying the document Commission Communication on a Feasibility Study for a Stabilization and Association Agreement 
between the European Union and Kosovo, published on October 23, 2013, had no remarks on the border related issues, including the cooperation between agencies involved in IBM.

Recommendation to draft this law came as a surprise not only to GoK officials, especially those involved in IBM but also to the representatives of international organizations embedded and working with the Kosovo Authorities, including EULEX. The only explanation for this recommendation that someone could come up with was that the expert doing the assessment on border related issues, part of the EC expert group doing the assessment on Visa Liberalization requirements, was from Finland. This explanation was given due to the fact that Finland is the only country in EU that has the Act on Cooperation between the Police, Customs and the Border Guard (687/2009), whose aim is to promote cooperation between the Police, Customs and the Border Guard (PCB authorities) and implement the joint strategies of PCB authorities so that the tasks laid down for these authorities and individual measures that are connected with the prevention, detection and investigation of crimes (combating of crime), control and monitoring and related international cooperation are carried out in an appropriate, efficient and cost-effective manner.

Despite all of the above, GoK with the aim of addressing all recommendations given by EC regarding the Visa liberalization Process, in its revised Legislative Agenda for 2013 included drafting the Law on Cooperation between Authorities Involved on Integrated Border Management. This Law has been approved on July 31st, 2013 by the Kosovo Parliament and in contains seven chapters with total of 23 articles. The aim of this law, according to its article 1 is to regulate cooperation between all authorities involved in the Integrated Border Management and to implement the joint strategies of such authorities so that the tasks laid down for these authorities and individual measures that are connected with the prevention, detection and investigation of criminal illegal activities, control and monitoring and related international cooperation are carried out in an appropriate, efficient and effective manner. In addition, this law contains provisions dealing with: Guiding Principles while Performing IBM Activities; Authorities Involved in IBM; Cooperation Between Agencies; IBM Executive Board; NCBM; Cooperation Between Authorities Involved in IBM in Local Level; Agreements Between Authorities; Joint Risk and Threats Analysis; Joint Operations and Actions and International Cooperation. This law did not introduce anything new compared what was already in place, a part from making certain requirements already foreseen in the IBM Strategy into articles of the law. Also, the structure of this law is similar to the IBM strategy, while the only EU document that has been referred to when drafting this law was the EC Guidelines for Integrated Border Management. These guidelines have been already introduced in the IBM strategy that was also referred to in the article 48 of the Law on Border Control. Finally, this law the same as the Law on Border Control, in its article 22 refers to the national strategy for IBM, by stating that Authorities involved in IBM shall realize their actual cooperation through the National Strategy for IBM without prejudice to provisions of this Law.

Considering that there is no EU Regulation or Directive that specifically addresses issues referred to this law and the fact that this law incorporated the EC Guidelines for Integrated Border Management we can conclude that this law is in harmony with EU legislation and best practices.

\section{Legis lative Framework In The Area Of Migration Management}

The area of migration management is fairly new in Kosovo, while the first legislative act covering this area was introduced only on May 1st, 2005, titled UNMNIK Regulation No. 2005/16 on the Movement of Pers ons into and out of Kosovo. The scope of this regulation was to regulate the movement of persons into and out of Kosovo, and it contained total of 27 articles. This regulation dealt with entry stay and exit, refugees and refugee status and it also contained few articles dealing with penalty provisions. This regulation was poor, while it failed to regulate the basic principles related to migration management, including: define a foreigner, define valid travel document; it did not specify temporary nor permanent stay, it lacked basic criteria based on which a person may/should be refused entry, like: threats to national security, sufficient means for living, health insurance, etc. In addition, in the area of refugees/asylum this regulation was very poor, as it tried to regulate this with only 6 articles which lacked the vast majority of principles dealing with this area. This regulation was the only piece of legislation dealing with migration management, including asylum, until initially July, 2008 when Law No 2008/03-L-066 on Asylum entered into force, respectfully January 2009, when the Law no.2008/03L-126 on Foreigners entered into force. Finally, the Law No.2009/03-L-136 on Granting the Permit for 
Work and Employment of Foreign Citizens on the RKS were both approved on July 172009 by the Kosovo Parliament, setting the basic legis lative framework covering the area of migration management. These laws were supposed to be in line with EU Acquis, especially: Directives on the conditions of admission of third-country nationals for studies and training (Directive 2004/114/E); on admitting thirdcountry nationals for research (Directive 2005/71/EC); on the right to family reunification (Directive 2003/86/EC), on long-term residents (Directive 2003/109/EC); Return Directive (Directive 2008/115/EC); on assistance in case of removal by air (Directive 2003/110/EC); on reception conditions for asylum-seekers (Directive 2003/9/EC); the Qualification Directive (Directive 2004/83/EC and Recast Directive 2011/95/EU); and the Asylum Procedures Directive (Directive 2005/85/EC); The Blue Card Directive (Directive 2009/50/EC) and the Directive providing for minimum standards for sanctions against employers of illegally staying third-country nationals (Directive 2009/52/EC). As it will be seen, these laws were only partially harmonized with the above mentioned EU Aquis, and created some conflicts and confusion between authorities implementing these laws.

A foreigner in Kosovo is considered any person who is not a citizen of the RKS. A citizenship of the RKS is determined based on the law on citizenship. According to article 2.1 .1 of this law, citizenship is considered to be as 'a legal bond between the State of the RKS and a person which establishes mutual rights and obligations'.

The area covering migration in Kosovo was regulated with three basic laws; Law No 2008/03-L-066 on Asylum, Law no.2008/03-L-126 on Foreigners and Law No.2009/03-L-136 on Granting the Permit for Work and Employment of Foreign Citizens on the RKS. These laws were in force until September 2013, when new laws have taken effect and abrogated the three previous ones. The two new laws are the Law on Asylum and the Law on Foreigners included also the provisions regarding employment of foreigners in Kosovo.

Even thought, the initial laws dealing with this area were drafted only in 2008, two of them (Foreigners and Asylum) were re-drafted in 2011, not until September 2013, Kosovo legislation covering this area failed to be in harmony with that of EU.

Initially, the Law on Foreigners failed to incorporate provisions deriving from the Directive on admitting third country nationals for research (Directive 2005/71/EC), Blue Card Directive (Directive 2009/50/EC), and the Directive for Providing for Minimum Standards for Sanctions against Employers of Illegally Staying Third-Country Nationals (Directive 2009/52/EC), some of its articles even though were in line with articles in the other EU regulations and directive, they were still vague in nature or had less detailed provisions compared to above mentioned directives and regulations. Initially, definitions provided in this law were not nearly in line with the definitions provided in the above EU regulations and directives. The law of 2008 contained only three definitions, while the law on 2013 contains twenty nine. The law of 2008 did not include some very important definitions, including: stateless person, travel document; carrier, daily migrant, residence permit, refugee, illegal employment, foreign employer, removal, illegal residence, family reunification, sponsor, etc. Lack of these definitions in this law made its implementation very hard and sometimes impossible.

There were other areas regulated by this law that were either not in line with the EU regulations and directives or were not specific enough, while a number of issues addressed by these regulations and directives were not included at all in this law. Among other things, there was a direct conflict between the Law on Foreigners and the Law for Issuing Work Permits for Foreigners. While this law requires from a foreigner to be initially equipped with a work permit then to apply for a resident permit, when intending to stay temporarily on the basis of employment, the law for is suing work permits to foreigners requires a foreigner to get the resident permit first than to apply for work permit. The law for issuing work permits for foreigners was drafted after the entry into force of the law on foreigners. In addition, this law also created confusion when is suing resident permits, by not defining a resident permit as such, while referring to it as ID card for foreigners, that was supposed to be issued separately, while also requiring is suance of a resident permit in a form of a sticker to be placed in the passport of the foreigner, disregarding the number of agreements that RKS had/has with certain countries on the free movement of people, allowing citizens of this countries to travel to Kosovo only by using ID or other identifiable document. Finally, this law did not provide for any penalty provisions, in cases when violations of its provisions would occur, making it even less implementable.

Law No.2009/03-L-136 on Granting the Permit for Work and Employment of Foreign Citizens on the RKS on the other hand is yet even poorer than the law on foreigners. Despite the fact that this law was 
drafted in July 2009, it failed to incorporate even the basic principles of the EU regulations and directives covering this area. Initially, almost none of the provisions of the Blue Card Directive (Directive 2009/50/EC) and the Directive providing for minimum standards for sanctions against employers of illegally staying third-country nationals (Directive 2009/52/EC) were not included in this law. Initially, this law did not provide for proper definitions, while its articles were very vague and did not include even some basic concepts covering this area, while it did not contain any provisions on; foreign employers, contractors, sub-contractors, posted workers, etc.

All of the above mentioned gaps and confusion created with the above mentioned laws were addressed in the new Law on Foreigners that entered into force on September 2013. This law initially merged the other two, while it provided for much more detailed and cleared provisions, and it incorporate d all of the provisions of the above mentioned EU directives and regulations covering this area. This law provides for clear definition of terms used in the law; it contains clear provisions on travel documents, both foreign and domestic; it regulates in detail issuance of visas; it regulates in detail entry, stay and exit of foreigners and employment of foreigners; it defines illegal residence and removal of foreigners; it contains sufficient legal protection of personal data; its contains clear provisions on integration of foreigners, and it provides for a list of penalty provisions when someone is in breach of these provisions. This law is in full accordance with EU Acquis covering the respective area, but there are a few issues that may arise during the implementation of this law. Initially, this law in its article ninety four, different from previous laws, provides for the Department for Citizenship, Asylum and Migration (DCAM), to is sue the order to leave, when foreigners are to be found staying illegally, while in the other hand in its provisions dealing with penalties it provides for police to issue fines. Initially, DCAM is an administrative body within Ministry of Internal Affairs (MIA) and has no executive authority; it cannot issue even fines when someone does not respect their order/refuse to leave. This competence should have been given to Kosovo Police (KP) considering their executive authority as well as their power to conduct inspections on premises when there is a suspicion that someone is staying illegally. Even though this may create certain confusion that may impact the full implementation of this law, this provision is still in line with EU Acquis, considering that EU regulations and directives are silent on who should be the body to is sue this order and they leave this up to member states to decide.

\section{Conclusion}

The area of Border and Management is still being developed in Kosovo while not only until September 2013; a proper legis lative framework covering this area was in place. It took around five years and three legis lative processes for Kosovo authorities to finally put in place proper laws that are harmonized with the EU Acquis. Initial laws covering this area were drafted only after the declaration of independence by the Kosovo Parliament, in February 2008, while these same laws had to be amended twice, initially in 2012 and then 2013, to have them in full accordance with the EU Acquis. Initial laws lacked number of important provisions, starting with the definitions of many important terms used in the respective area as well as penalty provisions that would guarantee a better implementation of these laws. In addition, these initial laws, created confusion among authorities involved in their implementation, while there were instance when they also created direct conflicts between the provisions of these laws.

However, in 2013, GoK established the respective work groups to amend and when necessary to rewrite these laws, while in August 2013 these same laws were approved by the Kosovo Parliament and in September of this year they entered into force. The new versions of these laws are in line with the EU Acquis, while they contain detailed provisions on all aspects covering this area and eliminated all of the conflicts between the previous versions of these laws. The legislative process of 2013, related to this area was also unique, considering that it related directly with the vis a liberalization process, while it merged two laws and it introduced a new law (on Cooperation Between Authorities Involved in IBM) making it the only such law in Europe and wider. This new law was requested by the EU experts involved in the assessment mission for visa liberalization, while there is no EU regulation or directive specifically covering this is sue.

Finally, despite the fact that these laws are in line with the EU Acquis, Kosovo authorities implementing the same will struggle in their efforts during their implementation, especially considering that fact that 
Kosovo still lacks some necessary infrastructure, like: Detention Center for Foreigners, having a semi established diplomatic and consular service and also having non- experience officers or with little experience in this area.

\section{References}

1. Craig, De Burca (2007, EU Law, Text, Cases and Materials, Fourth Edition, Oxford University Press.

2. Law on Integrated Management and Control of the State Border Remark: Law is approved by Assembly, date 21. 05. 2008 and promulgated by the Decree of the President of the Republic of Kosovo No. DL-021-2008, date 15.06.2008.

3. Law on cooperation between authorities involved on integrated border management, Remark: Law is approved by Assembly, date 31.07.2013, and promulgated by the Decree of the President of the Republic of Kosovo No.DL-40-2013, Date 19.08.2013.

4. Law on asylum, Remark: Law is approved by Assembly, date 21.12.2011, and promulgated by the Decree of the President of the Republic of Kosovo No.DL-57-2011, Date 30.12.2011.

5. Law on asylum, Remark: Law is approved by Assembly, date 31.07.2013, and promulgated by the Decree of the President of the Republic of Kosovo No.DL-39-2013, Date 19.08.2013.

6. Law on Foreigners Remark: Law is approved by Assembly, date 16.12. 2008 and promulgated by the Decree of the President of the Republic of Kosovo No. DL-069-2008, date 30.12.2008.

7. Law on foreigners, Remark: Law is approved by Assembly, date 21.12.2011, and promulgated by the Decree of the President of the Republic of Kosovo No.DL-056-2011, Date 30.12.2011.

8. Law on foreigners, Remark: Law is approved by Assembly, date 31.07.2013, and promulgated by the Decree of the President of the Republic of Kosovo No.DL-42-2013, Date 19.08.2013.

9. Law on State border control and surveillance, Remark: Law is approved by Assembly, date 21.12.2011, and promulgated by the Decree of the President of the Republic of Kosovo No.DL001-2012, Date 06.01.2012.

10. Law on amending and supplementing the Law no. 04-L-072 on state border control and surveillance, Remark: Law is approved by Assembly, date 31.07.2013, and promulgated by the Decree of the President of the Republic of Kosovo No.DL-48-2013, Date 19.08.2013.

11. Law No.03/L-136 on Granting Permit for Work and Employment of Foreign Citizens in Republic of Kosovo, 2009.

12. National Strategy of The Republic of Kosovo on Integrated Border Management, 2009.

13. REGULATION (EC) No 562/2006 OF THE EUROPEAN PARLIAMENT AND OF THE COUNCIL of 15 March 2006 establishing a Community Code on the rules governing the movement of persons across borders

14. (Schengen Borders Code), 2006.

15. COUNCIL REGULATION (EC) No 2007/2004 of 26 October 2004 establishing a European Agency for the Management of Operational Cooperation at the External Borders of the Member States of the European Union, 2004.

16. REGULATION (EC) No 1931/2006 OF THE EUROPEAN PARLIAMENT AND OF THE COUNCIL of 20 December 2006 laying down rules on local border traffic at the external land borders of the Member States and amending the provisions of the Schengen Convention, 2006.

17. EC Guidelines for Integrated Border Management in the Western Balkans, 2009.

18. REGULATION (EC) No 767/2008 OF THE EUROPEAN PARLIAMENT AND OF THE COUNCIL of 9 July 2008 concerning the Vis Information System (VIS) and the exchange of data between Member States on short-stay visas (VIS Regulation), 2008.

19. REGULATIONS REGULATION (EC) No 810/2009 OF THE EUROPEAN PARLIAMENT AND OF THE COUNCIL of 13 July 2009 establishing a Community Code on Visas (Visa Code), 2009.

20. DIRECTIVE 2011/98/EU OF THE EUROPEAN PARLIAMENT AND OF THE COUNCIL of 13 December 2011 on a single application procedure for a single permit for third-country nationals to reside and work in the territory of a Member State and on a common set of rights for third-country workers legally residing in a Member State, 2011. 
21. COUNCIL DIRECTIVE 2004/114/EC of 13 December 2004 on the conditions of admission of third-country nationals for the purposes of studies, pupil exchange, unremunerated training or voluntary service. 2004.

22. COUNCIL DIRECTIVE 2005/71/EC of 12 October 2005 on a specific procedure for admitting third-country nationals for the purposes of scientific research, 2005.

23. COUNCIL DIRECTIVE 2003/86/EC of 22 September 2003 on the right to family reunification, 2003.

24. COUNCIL DIRECTIVE 2003/109/EC of 25 November 2003 concerning the status of third-country nationals who are long-term residents, 2003.

25. COUNCIL DIRECTIVE 2009/50/EC of 25 May 2009 on the conditions of entry and residence of third-country nationals for the purposes of highly qualified employment, 2009.

26. DIRECTIVE 2008/115/EC OF THE EUROPEAN PARLIAMENT AND OF THE COUNCIL of 16 December 2008 on common standards and procedures in Member States for returning illegally staying third-country nationals, 2008.

27. COUNCIL DIRECTIVE 2003/110/EC of 25 November 2003 on assistance in cases of transit for the purposes of removal by air, 2003.

28. DIRECTIVE 2009/52/EC OF THE EUROPEAN PARLIAMENT AND OF THE COUNCIL of 18 June 2009 providing for minimum standards on sanctions and measures against employers of illegally staying third-country nationals, 2009.

29. COUNCIL DIRECTIVE 2003/9/EC of 27 January 2003 laying down minimum standards for the reception of asylum seekers, 2003.

30. Council Directive 2004/83/EC of 29 April 2004 on minimum standards for the qualification and status of third country nationals or stateless persons as refugees or as persons who otherwise need international protection and the content of the protection granted, 2004.

31. DIRECTIVE 2011/95/EU OF THE EUROPEAN PARLIAMENT AND OF THE COUNCIL of 13 December 2011 on standards for the qualification of third-country nationals or stateless persons as beneficiaries of international protection, for a uniform status for refugees or for persons eligible for subsidiary protection, and for the content of the protection granted (recast), 2011.

32. COUNCIL DIRECTIVE 2005/85/EC of 1 December 2005 on minimum standards on procedures in Member States for granting and withdrawing refugee status, 2005.

33. EU Visa Liberalisation with Kosovo Roadmap, 2012.

34. The Comprehensive proposal for Kosovo Status Settlemen, Report of the Special Envoy of the Secretary-General on Kosovo's future status, United Nations Office of the Special Envoy for Kosovo, 2007.

35. Kosovo Government LEGISLATIVE PROGRAM, 2013, Approved by Decision No. 02/110, 26.12.2012.

36. The Program of the Government of the Republic of Kosovo, 2011-2014.

37. Regulation of Rules and Procedure of the Government of the Republic of Kosovo No. 09/2011. 